\title{
EVALUATING THE AIRTIGHTNESS OF RESIDENTIAL BUILDINGS BY USING PREDICTIVE MODELS
}

\author{
Hrvoje Krstić \\ Josip Juraj Strossmayer University of Osijek, Faculty of Civil Engineering Osijek, Assistant Professor \\ Corresponding author: hrvojek@gfos.hr \\ Željko Koški \\ Josip Juraj Strossmayer University of Osijek, Faculty of Civil Engineering Osijek, Associate Professor \\ Dario Zečević \\ Josip Juraj Strossmayer University of Osijek, Faculty of Civil Engineering Osijek, Student
}

\begin{abstract}
A building's energy consumption can be greatly reduced by improving its airtightness. Thus, when designing new and retrofitting existing buildings, it is important to accurately calculate energy losses caused by uncontrolled air leakage. A building's airtightness can be measured by a pressurization test but only at the final stage of construction, and for large buildings this procedure can be very expensive and often produces results of questionable quality. Another way to evaluate airtightness is by using predictive models. In this study, we compare three predictive models for determining airtightness, using an airtightness database from buildings in the city of Osijek and in a suburban area. Using these models, we calculated airtightness values for 20 buildings and compared these predictions with measured results.
\end{abstract}

Keywords: Airtightness, predictive models, blower-door method, construction techniques, construction and lifecycle costs

\section{MODELI PROCJENE ZRAKOPROPUSNOSTI STAMBENIH ZGRADA}

Sažetak: Smanjenje potrošnje energije važno je iz ekoloških, ali i ekonomskih razloga. Zbog visoke cijene energenata moguće je postići velike uštede smanjivanjem zrakopropusnosti. Iz tih razloga potrebno je postići što veću točnost prilikom izračuna gubitaka energije zbog prodora vanjskog zraka, kako pri projektiranju novih građevina, tako i pri rekonstrukciji postojećih. Konačna vrijednost zrakopropusnosti može se dobiti provođenjem tlačnog ispitivanja, ali tek nakon što je izvođenje građevine završeno ili je u završnoj fazi izvedbe. Za jako velike građevine taj je postupak skup i često nedovoljne preciznosti. Alternativa mjerenju je procjena zrakopropusnosti pomoću modela predikcije. Svrha ovoga rada je procjena mogućnosti primjene modela predikcije za određivanje zrakopropusnosti. Korištena su tri modela te baza podataka mjerenja zrakopropusnosti s područja grada Osijeka i okolice. Pomoću modela je izračunata zrakopropusnost za 20 zgrada te uspoređena s izmjerenim vrijednostima.

Ključne riječi: zrakopropusnost, modeli predikcije, Blower-door metoda, tehnologija građenja, troškovi građenja i životnog ciklusa 


\section{INTRODUCTION}

Directive 2010/31/EU on the energy performance of buildings introduced the concept of the "nearly zero-energy building." Such buildings, with very good energy performance, could be mostly or fully powered by renewable energy, including energy produced on-site or nearby [1]. In this directive, the member states agreed to ensure that, after 31 December 2018, new buildings occupied and owned by public authorities will be nearly zero-energy buildings and that, by 31 December 2020, all new buildings will be nearly zero-energy buildings [1]. The member states agreed to take the necessary measures to ensure that, when buildings undergo major renovation, the energy performance of the buildings or their renovated parts will be upgraded to meet the minimum energy performance requirements [1].

When designing a building, it is rational to both insulate a building and improve the building envelope's airtightness [2]. Airtightness affects a building's energy efficiency, thermal comfort, and indoor air quality, so understanding it is important in designing new buildings and retrofitting existing buildings [3]. By modeling a building, it is possible to asses its airtightness even early in its design, which allows the designer to choose among various construction techniques based on how they affect energy efficiency and the costs of construction and maintenance. Modeling is also useful when retrofitting existing buildings. The most important reasons to retrofit a building are to decrease its energy demands and cost, to reduce the insurance cost of its regulated operating conditions, and to meet the requirements of its users.

To measure a building's airtightness, a blower door is used to assess the relationships between the pressure difference over the building envelope, $\Delta \mathrm{P}[\mathrm{Pa}]$, and the airflow rate through the building envelope, $\mathrm{Q}$ $\left[\mathrm{m}^{3} / \mathrm{h}\right]$ [4]. The "building envelope" refers to several types of opaque and transparent perimeter structures or elements, which separate the internal heated (cooled) space from the external unheated (uncooled) space.

Predicting airtightness gives insight into the characteristics of residential unit envelopes without the need to conduct field tests, accelerating the preparation in building reconstruction [2].

In this research, we evaluate three predictive models for assessing building airtightness. To compare these models, we use an airtightness database from the city of Osijek and a nearby suburban area. Using each of the three models, we calculated the airtightness for 20 buildings.

\section{PREVIOUS RESEARCH}

\subsection{Predicting airtightness by using a neural network from Croatia}

In a Croatian study, Krstić et al. created a predictive model that would give basic insight into the characteristics of residential unit envelopes without the need to conduct field measurements, using neural networks and an airtightness database comprising 58 local residential units during 2014 [2]. To make the new predictive model, they created a system to evaluate the input parameters found during the study to affect the buildings' airtightness. The input data for the airtightness database were classified into four groups: the opaque part of the residential unit envelope, the transparent part of the residential unit envelope, the proportion of transparent parts in the residential unit envelope, and the percentage of exposure in the residential unit envelope [2].

These parameters are known in the early design phase of a building project and should be considered when analyzing a building's energy efficiency and lifecycle costs. These parameters are also important when retrofitting existing buildings to best improve their energy efficiency and calculate the retrofit's cost savings over the building's lifecycle [2].

The input parameters of the opaque and transparent parts of the residential unit envelopes also include the characteristics of the materials and structures used in determining the corrective factors. A corrective factor is a number associated with input parameters that depends on various characteristics, as shown in [2]. Higher corrective factors were associated with building envelope elements that had better theoretical airtightness (i.e., thicker construction elements such as walls, ceilings, and floors), less-porous materials, and high-quality openings (from the influence of the glazing, frame material, etc.) [2]. The corrective factor depended on the quality of the building construction, how well the elements were maintained during the building's lifecycle, the design details, the construction technique, and the age of the construction elements and openings. 
In the current research, we examine whether neural networks can be used as a predictive model for the airtightness of local residential units. Their predictions showed that the neural network was well suited to analyzing this type of problem. The correlation coefficient between the measured data and the neural network prediction was $95.37 \%$, and the mean prediction error was 0.835 . The basic advantage of this type of predictive model was that it can quickly assess airtightness, but the basic disadvantage was the relatively small number of residential units used to train the neural network [2].

\subsection{Predicting airtightness by using a regression model from Greece}

In a Greek study, Sfakianaki et al. calculated the airtightness of 20 single-family buildings under natural conditions in Attica, Greece, during the summer of 2005, at a pressure difference of $50 \mathrm{~Pa}$ between the indoors and outdoors [5]. They showed that an important factor related to a building's airtightness is its total window frame length divided by its net volume. They estimated the total window frame length for each building, divided this value by the building's net volume, and then defined a frame length factor (FLF), the ratio of the total frame length (TFL) to the net volume of the building (NV) [5].

They classified houses into three airtightness categories (low, medium, and high) according to EN ISO 13790. However, the samples of buildings belonging to the medium and high airtightness categories were statistically uneven. This may have been caused by variations in ambient conditions, such as wind speed and the difference between indoor and outdoor temperatures, and by variations in construction characteristics. Given this statistical nonuniformity, in future research it might be necessary to redefine the airtightness range for each category or to create a new category between two existing ones [5].

There was no correlation between the infiltration measurements in natural conditions and the total window frame length. Sfakianaki et al. concluded that it will be necessary to study how climatic conditions affect these infiltration measurements. There was a correlation between the measured airtightness at a 50-Pa pressure difference and the total window frame length, mainly for the buildings in the low airtightness category. The total frame length affected the air leakage of each building and its airtightness. However, the sample of buildings was very small, and many experiments are required to produce definitive conclusions [5].

\subsection{Predicting airtightness by using a regression model from Sweden}

In a Swedish study, Zou et al. identified various factors related to airtightness by using a literature review, questionnaires, and interviews. Based on these findings, they established a database of building airtightness, making it possible to predict the airtightness of Swedish single-family houses [6]. They investigated 374 buildings to determine the factors that most influenced airtightness. In addition, they performed statistical analyses of 185 airtightness measurements of Swedish single-family houses, using the F-test and the Student's T-test [6]. The results of these analyses showed that these buildings' airtightness values depended much on their focus on energy efficiency, use of an installation layer, year of construction, and number of stories. By contrast, the predominant wall materials and foundation type mattered little: they were not statistically significant. Furthermore, they made three predictions of airtightness values for Swedish single-family houses [6].

To predict airtightness in this model, the following data is needed:

The air flow through the permeable materials [6]:

$$
R_{a}=A_{\text {inf }} \cdot \frac{k}{\mu} \cdot \frac{\Delta P}{d}
$$

where $R_{a}\left(m^{3} / \mathrm{s}\right)$ is Air flow rate; $A_{\text {inf }}\left(m^{2}\right)$ is Infiltrated area by air; $k\left(m^{2}\right)$ is Permeability; $\mu(\mathrm{kg} / \mathrm{m} \bullet \mathrm{s})$ is Kinematic viscosity of air; $d(m)$ is Thickness of wall and ceiling

The air flow through the air gap [6]:

$$
S_{g}=\frac{12 \cdot \mu \cdot L}{b^{2} \cdot A}
$$

where [6] $S_{g}\left(P a \cdot s / m^{3}\right)$ is resistance of air gap; $L(m)$ is Thickness of the building component; $b(m)$ is Height of air gap; $A\left(\mathrm{~m}^{2}\right)$ is Area of air gap; $\mu\left(\mathrm{Ns} / \mathrm{m}^{2}\right)$ is Kinematic viscosity of air; $\mathrm{S}_{\mathrm{e}}\left[\mathrm{Pa} /\left(\mathrm{m}^{3} / \mathrm{s}\right)\right]$ is Air flow resistance

Finally, the air flow rate $R_{a}\left[m^{3} / s\right]$ : 


$$
R_{a}=\frac{1}{2 \cdot S_{e}^{\prime}}\left(\sqrt{S_{g}^{2}+4 \Delta P \cdot S_{e}^{\prime}}-S_{g}\right)
$$

where $[6] \Delta \mathrm{P}[\mathrm{Pa}]$ is the pressure difference over the building envelope.

The results predicted by the models from Croatia and Greece agree well with the measured data, with differences of $0.7 \%$ and $16 \%$, respectively. However, in the model from Sweden, because there is little information on the key factors related to airtightness, its predicted value deviates remarkably from the average measured data (57\%). More measured data must be fed into this database to refine the model's prediction [6].

\section{USING THE PREDICTIVE MODELS}

\subsection{Residential unit database}

The database we used comprises 20 residential buildings: ten in the city of Osijek, and ten in nearby suburban areas. The measured airtightness values at a pressure difference of $50 \mathrm{~Pa}(\mathrm{n} 50)$ in this database ranged from 0.86 to $10.951 / \mathrm{h}$. These residential buildings were built between 1912 and 2005. These buildings are the part of the database used to train the neural network in the Croation model, as described in chapter 2.1 [2].

\subsection{Predicted results}

Figures 1, 2, and 3 plot the measured values of the residential units' airtightness and those predicted by the models from the Croatian [2], Greek [5], and Swedish [6] studies, respectively.

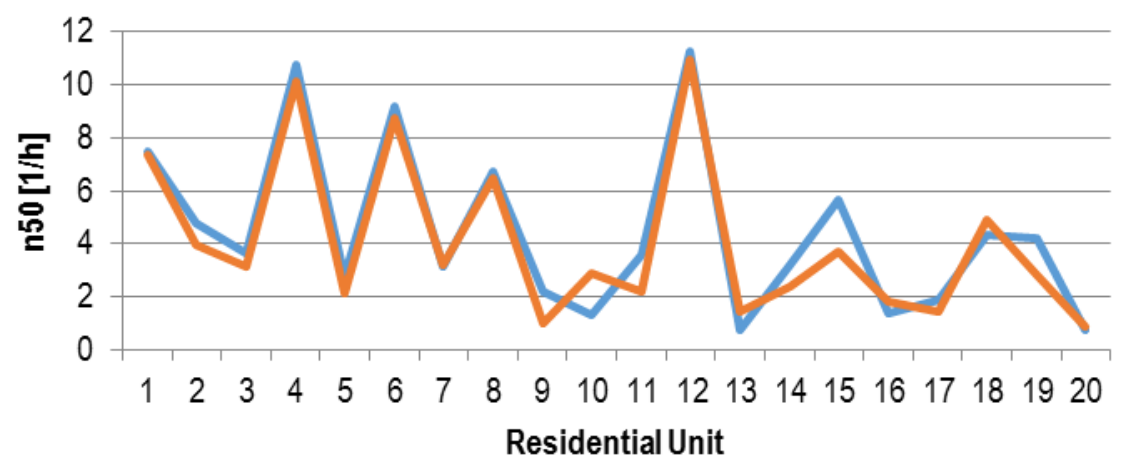

Model prediction Measured value

Figure 1 Results of airtightness prediction model from Croatia [2]

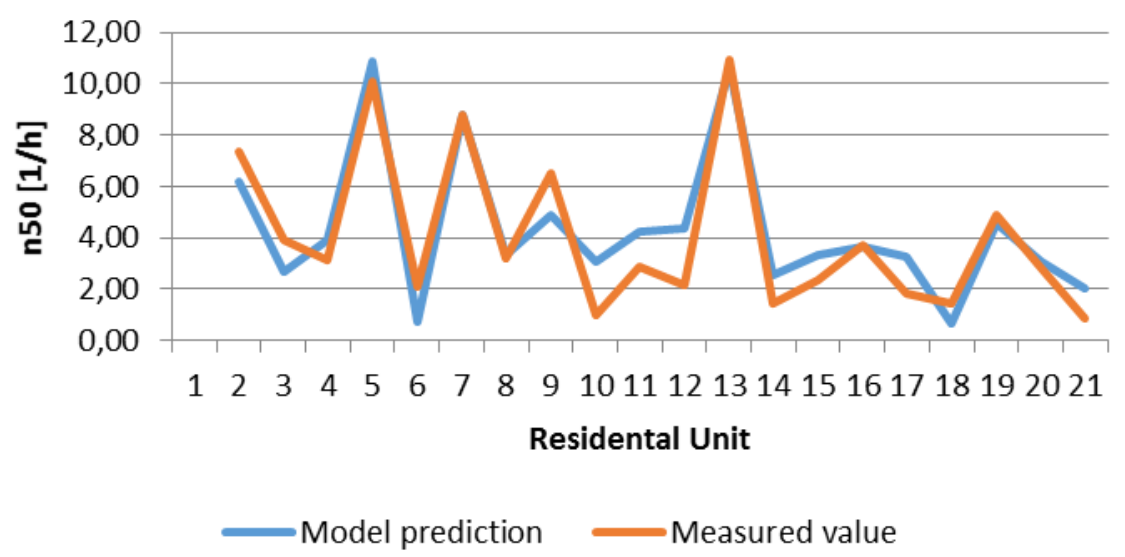

Figure 2 Results of airtightness prediction model from Greece [5] 


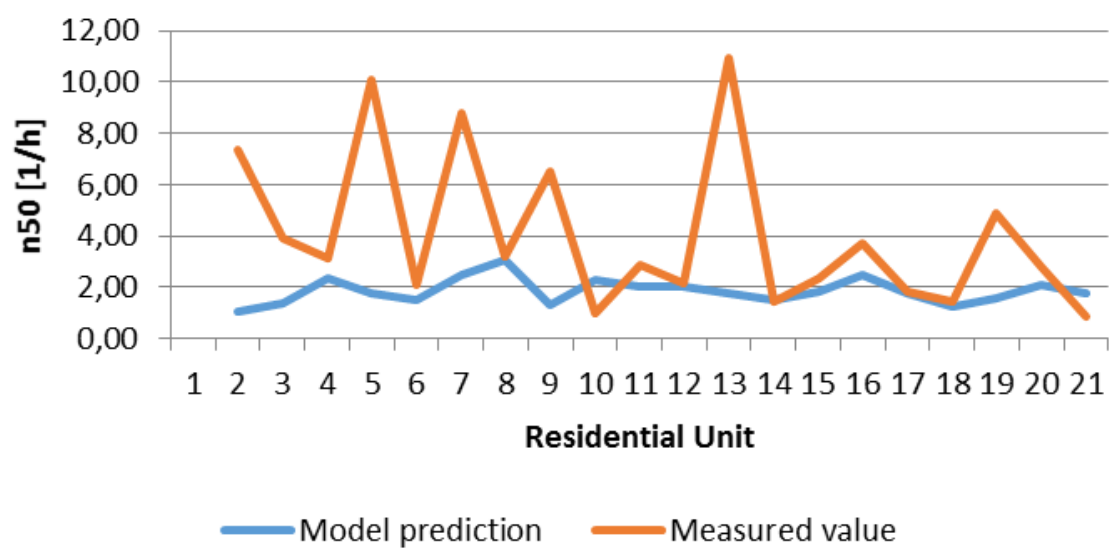

Figure 3 Results of airtightness prediction model from Sweden [6]

\subsection{Statistical validation of models}

Models are usually validated either for business reasons or to minimize loss or bias [7]. Validation is done to ensure that the model will work in the future for new, similar data and to avoid over-fitting or under-fitting of the model $[8,9]$.

Some statistical methods used to validate models are as follows [8, 10-12]:

Root-mean-squared error of prediction (RMSEP), defined as the square root of the average of the squared differences between the predicted and measured $y$-values of the validation objects:

$R M S E P=\sqrt{\frac{\sum_{i=1}^{n}\left(\hat{y}_{i}-\tilde{y}_{i}\right)^{2}}{n}}$

Bias, the averaged difference between the predicted and measured $y$-values for all samples in the validation set:

Bias $=\frac{\sum_{i=1}^{n}\left(\hat{y}_{i}-\tilde{y}_{i}\right)}{n}$

The accuracy of a model (Model Accuracy, AC) is the percentage difference between the predicted and actual airtightness. It can be calculated as [13]:

$A_{C}=\left[\frac{P C-A C}{A C}\right] \cdot 100 \%$

where Ac is Accuracy of the calculated value; PC is Predicted values; $A C$ is Actual values.

The closer the AC of a model (Mean Model Accuracy, $\overline{A_{C}}$ ) is to zero, the more accurate the model is. The mean accuracy of a model for a series of tests is the arithmetic average of $A C$ [13]:

$\bar{A}_{C}=\frac{\sum_{i=1}^{n} A_{C}}{n}$

where Ac is Accuracy of the calculated airtightness from one data set; $n$ is Number in data set.

A mean model accuracy of zero means that the model does not, on average, underestimate or overestimate the measured airtightness.

The precision of the model is determined from the scatter of its individual accuracies over a series of years in one building or over a series of buildings in one category. This dispersion is represented by the standard deviation (std) of AC. The total accuracy (Am) of the model is as follows [13]:

$A_{m}=\bar{A}_{C}-s t d$ of $A_{C}$ 
To statistically validate the three models, we calculated the aforementioned parameters and presented them in Tables 1-3. Figure 4 plots the results of the model validation.

Table 1 Statistical validation of the airtightness prediction model from Croatia

\begin{tabular}{cccccc}
\hline \multirow{2}{*}{ Residential Unit } & $\begin{array}{c}\text { Measured value, } \mathrm{n}_{50} \\
\left(\hat{y}_{i}\right)\end{array}$ & $\begin{array}{c}\text { Predicted value, } \mathrm{n}_{50} \\
\left(\tilde{y}_{i}\right)\end{array}$ & $\left(\tilde{y}_{i}-\hat{y}_{i}\right)$ & $\left(\hat{y}_{i}-\tilde{y}_{i}\right)^{2}$ & $\mathrm{AC}(\%)$ \\
\hline 1. & 7.35 & 7.48 & 0.13 & 0.0169 & $1.77 \%$ \\
2. & 3.94 & 4.75 & 0.81 & 0.6561 & $20.56 \%$ \\
3. & 3.16 & 3.63 & 0.47 & 0.2209 & $14.87 \%$ \\
4. & 10.12 & 10.75 & 0.63 & 0.3969 & $6.23 \%$ \\
5. & 2.12 & 2.75 & 0.63 & 0.3969 & $29.72 \%$ \\
6. & 8.77 & 9.16 & 0.39 & 0.1521 & $4.45 \%$ \\
7. & 3.22 & 3.13 & -0.09 & 0.0081 & $-2.80 \%$ \\
8. & 6.49 & 6.76 & 0.27 & 0.0729 & $4.16 \%$ \\
9. & 0.99 & 2.22 & 1.23 & 1.5129 & $124.24 \%$ \\
10. & 2.86 & 1.32 & -1.54 & 2.3716 & $-53.85 \%$ \\
11. & 2.18 & 1.55 & 1.37 & 1.8769 & $62.84 \%$ \\
12. & 10.95 & 0.35 & 0.1225 & $3.20 \%$ \\
13. & 1.45 & -0.76 & 0.4761 & $-47.59 \%$ \\
14. & 3.18 & 0.81 & 0.6561 & $34.18 \%$ \\
15. & 2.37 & 1.96 & 3.8416 & $53.12 \%$ \\
16. & 3.65 & -0.45 & 0.2025 & $-24.86 \%$ \\
17. & 1.36 & 0.41 & 0.1681 & $28.28 \%$ \\
18. & 1.81 & -0.55 & 0.3025 & $-11.27 \%$ \\
19. & 1.45 & 1.36 & 1.8769 & $48.58 \%$ \\
20. & 4.88 & -0.1 & 0.01 & $-11.63 \%$ \\
\hline
\end{tabular}

Table 2 Statistical validation of the airtightness prediction model developed in Greece

\begin{tabular}{cccccc}
\hline \multirow{2}{*}{ Residential Unit } & $\begin{array}{c}\text { Measured value, } \mathrm{n}_{50} \\
\left(\hat{y}_{i}\right)\end{array}$ & $\begin{array}{c}\text { Predicted value, } \mathrm{n}_{50,} \\
\left(\tilde{y}_{i}\right)\end{array}$ & $\left(\tilde{y}_{i}-\hat{y}_{i}\right)$ & $\left(\hat{y}_{i}-\tilde{y}_{i}\right)^{2}$ & $\mathrm{AC}(\%)$ \\
\hline 1. & 7.35 & 6.17 & -1.18 & 1.3876 & $-16.03 \%$ \\
2. & 3.94 & 2.69 & -1.25 & 1.5737 & $-31.84 \%$ \\
3. & 3.16 & 3.91 & 0.75 & 0.5552 & $23.58 \%$ \\
4. & 10.12 & 10.87 & 0.75 & 0.5663 & $7.44 \%$ \\
5. & 2.12 & 0.70 & -1.42 & 2.0209 & $-67.06 \%$ \\
6. & 8.77 & 8.79 & 0.02 & 0.0003 & $0.18 \%$ \\
7. & 3.22 & 3.35 & 0.13 & 0.0163 & $3.97 \%$ \\
8. & 6.49 & 4.91 & -1.58 & 2.4990 & $-24.36 \%$ \\
9. & 0.99 & 3.08 & 2.09 & 4.3735 & $211.24 \%$ \\
10. & 2.86 & 4.27 & 1.41 & 1.9930 & $49.36 \%$ \\
11. & 2.18 & 4.38 & 2.20 & 4.8220 & $100.73 \%$ \\
12. & 10.61 & -0.34 & 0.1144 & $-3.09 \%$ \\
13. & 2.57 & 1.12 & 1.2540 & $77.23 \%$ \\
14. & 1.45 & 0.97 & 0.9402 & $40.91 \%$ \\
15. & 2.34 & -0.06 & 0.0041 & $-1.74 \%$ \\
16. & 3.37 & 1.47 & 2.1606 & $81.21 \%$ \\
17. & 3.69 & -0.77 & 0.5986 & $-53.36 \%$ \\
18. & 1.81 & -0.32 & 0.0993 & $-6.46 \%$ \\
19. & 1.45 & 0.68 & 0.28 & 0.0793 & $9.99 \%$ \\
20. & 4.88 & 1.20 & 1.4390 & $139.49 \%$ \\
\hline
\end{tabular}


Table 3 Statistical validation of the airtightness prediction model developed in Sweden

\begin{tabular}{|c|c|c|c|c|c|}
\hline Residential Unit & $\begin{array}{l}\text { Measured value, } \mathrm{n}_{50} \\
\left(\hat{y}_{i}\right)\end{array}$ & $\begin{array}{l}\text { Predicted value, } \mathrm{n}_{50}, \\
\left(\tilde{y}_{i}\right)\end{array}$ & $\left(\tilde{y}_{i}-\hat{y}_{i}\right)$ & $\left(\hat{y}_{i}-\tilde{y}_{i}\right)^{2}$ & $\mathrm{AC}(\%)$ \\
\hline 1. & 7.35 & 1.08 & 6.27 & 39.2666 & $-85.26 \%$ \\
\hline 2. & 3.94 & 1.37 & 2.57 & 6.5932 & $-65.17 \%$ \\
\hline 3. & 3.16 & 2.33 & 0.83 & 0.6966 & $-26.41 \%$ \\
\hline 4. & 10.12 & 1.77 & 8.35 & 69.7788 & $-82.54 \%$ \\
\hline 5. & 2.12 & 1.51 & 0.61 & 0.3681 & $-28.62 \%$ \\
\hline 6. & 8.77 & 2.48 & 6.29 & 39.5195 & $-71.68 \%$ \\
\hline 7. & 3.22 & 3.04 & 0.18 & 0.0319 & $-5.54 \%$ \\
\hline 8. & 6.49 & 1.35 & 5.14 & 26.4629 & $-79.26 \%$ \\
\hline 9. & 0.99 & 2.32 & -1.33 & 1.7705 & $134.40 \%$ \\
\hline 10. & 2.86 & 2.00 & 0.86 & 0.7386 & $-30.05 \%$ \\
\hline 11. & 2.18 & 2.00 & 0.18 & 0.0308 & $-8.05 \%$ \\
\hline 12. & 10.95 & 1.77 & 9.18 & 84.3611 & $-83.88 \%$ \\
\hline 13. & 1.45 & 1.54 & -0.09 & 0.0080 & $6.18 \%$ \\
\hline 14. & 2.37 & 1.82 & 0.55 & 0.3038 & $-23.26 \%$ \\
\hline 15. & 3.69 & 2.46 & 1.23 & 1.5086 & $-33.29 \%$ \\
\hline 16. & 1.81 & 1.80 & 0.01 & 0.0001 & $-0.49 \%$ \\
\hline 17. & 1.45 & 1.23 & 0.22 & 0.0488 & $-15.24 \%$ \\
\hline 18. & 4.88 & 1.55 & 3.33 & 11.1147 & $-68.32 \%$ \\
\hline 19. & 2.82 & 2.09 & 0.73 & 0.5351 & $-25.94 \%$ \\
\hline \multirow[t]{3}{*}{20.} & 0.86 & 1.75 & -0.89 & 0.7961 & $103.75 \%$ \\
\hline & & & $\sum=-44.22$ & $\sum=283.9338$ & $\Sigma=-488.66 \%$ \\
\hline & & & Bias $=-2.211$ & RMSEP $=3.7678$ & $\begin{array}{c}\bar{A} c=-24.43 \% \\
\text { std }=0.5779 \\
A_{m}=-82.22 \%\end{array}$ \\
\hline
\end{tabular}

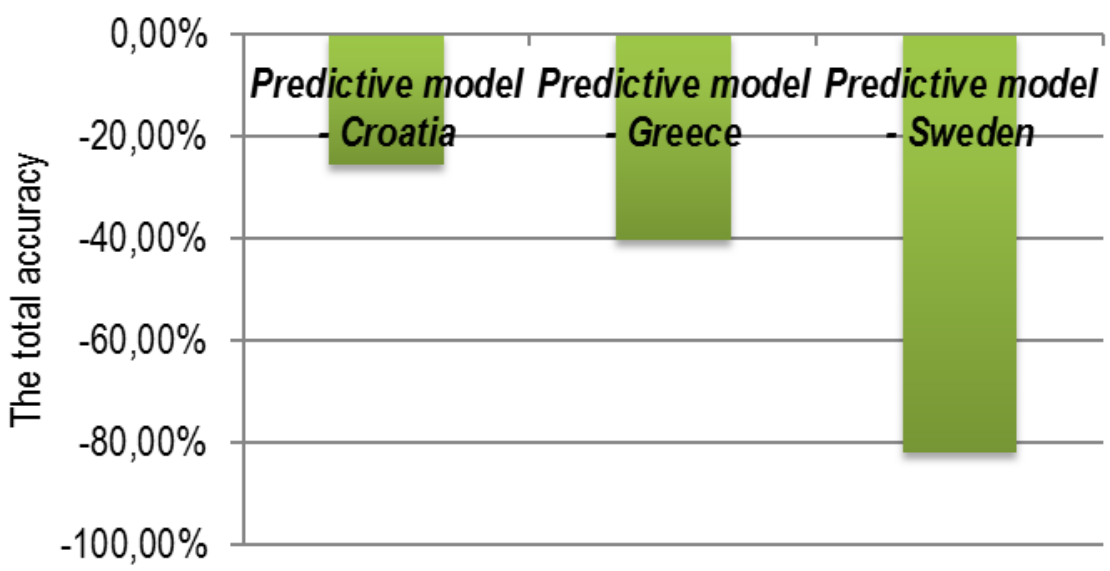

Figure 4 Total accuracy (Am) of the predictive models

As expected, the predictive model from Croatia produced the best predictions, according to the total model accuracy (Am). This probably occurred because the residential units used for validation originated from the database used to train the neural network.

The predictive model from Greece shows potential for further research and development, having a total accuracy of $40.30 \%$.

The predictive model from Sweden shows very limited possibilities for predicting the airtightness of residential units, even though it was the model constructed from the largest database: 374 residential buildings.

\section{CONCLUSION}

The predictive model from Croatia produced the best predictions, according to the total model accuracy (Am). This could have been caused by over-fitting, mentioned in chapter 3.3, which itself could have been caused by the residential units used in validation originating from the database used to train the neural network. To avoid over-fitting, the model should be tested on a new set of residential units in Croatia, another country, or some 
combination. The Croatian model used a small sample of residential units from Serbia, described in [14], and the results showed excellent potential for further development.

Currently the Croatian model is being tested on larger set of residential and office buildings in Poland. So far it shows great promise in predicting airtightness. However, this model uses corrective factors as input parameters for the neural network, and some of these parameters suffer from subjective assessment. This issue is the main disadvantage of the model, and it should be accounted for when predicting airtightness. The procedure is advantageous, however, in that it is simple and does not require much data for assessment.

The predictive model from Greece produced somewhat good results and shows potential for further research and development. The model is very simple and does not use much data. This is the great advantage compared to the other two models, but the results presented here should be taken with skepticism, mainly because this model was developed by using only 20 residential buildings, and especially because the Croatian model used 58 residential buildings and the Swedish model used a sample of 374 residential buildings, almost 19 times bigger.

The authors of the model from Greece stated themselves that, according to a statistical evaluation, the samples of the buildings in the low airtightness category were statistically homogeneous, but the samples of buildings in the medium and high airtightness categories were statistical uneven. They explain this by giving possible reasons of variations in ambient conditions and construction characteristics. Also, they did not account for the maintenance intervals, frame lifecycle, and the quality of the frames themselves.

The predictive model from Sweden showed poor results in predicting the airtightness in residential units, even though it was the model constructed from the largest database: 374 residential buildings. Furthermore, this model required much more data and more calculations to obtain the input parameters than did the other models. The discrepancy between the measured and predicted results can be partially explained by the differences in the systems and building technology in northern Europe and in southern Europe (Croatia and Greece). In northern Europe, it is common to make prefabricated houses from wood, so the authors probably gave some other model input parameters more attention. Northern European buildings also have different lifecycles, maintenance intervals, energy needs, and associated costs than those commonly built in Croatia and Greece.

Predicting the airtightness of residential buildings by using models is important in reducing testing costs and fulfilling climatic conditions. Based on our findings, there is great promise in airtightness models. However, such models will likely need to be tuned to local or regional conditions, and one should not create a universal mathematical model for predicting airtightness. The first step in improving the accuracy of these models should be making a larger database that covers a wide range of locally representative units in terms of construction type and building age or the year of retrofitting.

\section{References}

[1] Directive 2010/31 EU of the European Parliament and the Council of 19 May 2010 on the energy performance of buildings. Official Journal of the European Communities. L 153/21-2.

[2] Krstić, H. et al. 2014: Application of Neural Networks in Predicting Airtightness of Residential Units. Energy and Buildings, 84, pp. 160-168. DOI: 10.1016/j.enbuild.2014.08.007

[3] Sinnott, D.; Dyer, M. 2012: Air-tightness field data for dwellings in Ireland. Building and Environment, 51(0), pp. 269-275. DOI: 10.1016/i.buildenv.2011.11.016

[4] Relander, T.-O.; Holøs, S.; Thue, J. V. 2012: Airtightness estimation-A state of the art review and an en route upper limit evaluation principle to increase the chances that wood-frame houses with a vapour- and wind-barrier comply with the airtightness requirements. Energy and Buildings, 54(0), pp. 444-452. DOI: 10.1016/j.enbuild.2012.07.012

[5] Sfakianaki, A. et al. 2008: Air tightness measurements of residential houses in Athens, Greece. Building and Environment, 43(4), pp. 398-405. DOI: 10.1016/i.buildenv.2007.01.006

[6] Zou, Y. 2010: Classification of buildings with regard to airtightness, in Department of Civil and Environmental Engineering 2010, Chalmers University of Technology: Göteborg, Sweden, p. 100.

[7] Guszcza, J. 2005: The Basics of Model Validation, CAS Predictive Modeling Seminar: Chicago.

[8] Mathisen, R. 1999: On-line NIR analysis in a high density polyethene plant, evaluation of sampling system and optimal calibration strategy. Telemark College, Department of Technology. 
[9] Dunn, G. et al. 2003: Describing, explaining or predicting mental health care costs: a guide to regression models. British Journal of Psychiatry, 183. http://dx.doi.org/ 10.1192/bjp.183.5.398

[10] Yeniay, O.; Goktas, A. A. 2001: Comparison of partial least squares regression with other prediction methods. Hacettepe Journal of Mathematics and Statistics, 31.

[11] Liu, H. et al. 2009: Regression models for estimating product life cycle cost. Journal of Intelligent Manufacturing, 20. http://dx.doi.org/10.1007/s10845-008-0114-4

[12] Stepwise Selecting Models, 2007, The MathWorks, Inc.

[13] Al-Hajj, A.; Horner, M. W. 1998: Modelling the running costs of buildings. Construction Management and Economics, 16, pp. 459-470. http://dx.doi.org/10.1080/014461998372231

[14] Krstić, H.; Otković, I. I.; Todorović, G. Validation of a model for predicting airtightness of residential units, in 6th International Building Physics Conference, IBPC 20152015: Torino, Italy. 